\title{
Foraging behaviour of Brown Boobies Sula leucogaster in Anguilla, Lesser Antilles: Preliminary identification of at-sea distribution using a time-in-area approach
}

\author{
LOUISE M. SOANES, JENNIFER A. BRIGHT, MARK BOLTON, \\ JAMES MILLETT, FARAH MUKHIDA and JONATHAN A. GREEN
}

\section{Summary}

Seabird populations breeding in the UK Overseas Territories remain relatively understudied compared to UK seabird populations, despite their international importance. Here we present results from one of the first seabird tracking studies in the Caribbean region, of Brown Boobies Sula leucogaster breeding on the Important Bird Area (IBA) of Dog Island, Anguilla. Birds were tracked for 5-7 days during the chick-rearing period using GPS data loggers. We assess how representative the at-sea areas of use (utilisation distributions) identified from our sample of 16 birds are likely to be of those of the whole breeding colony, and examined the effect that grid cell size used in the 'time-in-area' analytical approach has on these predictions. We also assess the effectiveness of the BirdLife International's seaward extension approach to marine IBA designation, where terrestrial IBAs are buffered a set distance using existing information on the foraging radii of the same or similar breeding species. Foraging trips were $125.3 \pm 54.4$ (SD) km long and lasted for $5.6 \pm 1.95 \mathrm{hrs}$ on average. Birds travelled into the waters of four neighbouring territories; Saint Martin, Saba, Saint Eustatius and Saint Barthelemy. Our models suggest that many more individuals would need to be tracked to fully identify important at-sea areas for this colony, although this depends on the scale that important areas are defined. Whilst a smaller grid cell size may be necessary for assessing fine-scale habitat use, a larger grid cell size may be more appropriate for marine spatial planning processes. Although the BirdLife Seaward extension approach using maximum foraging distance recorded from Brown Boobies at a Mexican colony predicted a smaller foraging area than that used by Dog Island birds this approach still incorporated at least $99 \%$ of their $50 \%$ UD, $98 \%$ of their $75 \%$ UD and $86 \%$ of the $95 \%$ UD.

\section{Introduction}

The UK Overseas Territories (hereafter UKOTs) are home to more threatened bird species than the whole European continent, but this bird life, including the UKOTs' globally important seabird populations are relatively understudied (Sanders 2006, Hilton and Cuthbert 2010), and in addition environmental legislation is often weak, absent or unenforced (RSPB/ FIELD 2013). This is despite the many threats facing seabirds breeding in the UKOTs such as introduced species (Hilton and Cuthbert 2010), habitat degradation (Croxall et al. 2012), 
changes in fishery practice (Bertrand et al. 2012) and climate change (Gremillet and Boulinier 2009), which are as great or greater than those facing their UK counterparts. Designation of terrestrial and marine Important Bird Areas (IBAs) are used to highlight priority areas for seabird conservation, and can be used to inform marine spatial planning and design of Marine Protected Areas (Arcos et al. 2012, Le Corre et al. 2012).

Marine IBAs aim to capture the key at-sea areas used by seabirds when undertaking activities such as foraging, resting and rafting. Using tracking technology to record the at-sea distribution of seabirds breeding on terrestrial IBAs is one approach to collecting the data to help identify marine IBAs (Burger and Shaffer 2008, Lewison et al. 2012). However, logistical and financial constraints preclude tracking birds from every major seabird colony. So, in the absence of sitespecific data, BirdLife International (2010) advocates the use of a simple seaward extension around terrestrial IBAs with seabird colonies. The distance of the extension is based on literature reviews of the known foraging ranges of the key species present. Where spatial data do exist for a given colony, a range of more refined analytical methods can be used to identify key areas for the colony (BirdLife International 2010, O'Brien et al. 2012, Oppel et al. 2012, Tancell et al. 2013). For example, 'first passage time analysis' and 'area restricted search patterns' identify foraging sites by using a high turning rate or the speed of travel as an indicator of foraging behaviour (Pinaud 2008, Suryan et al. 2004) whereas the kernel density estimation approach uses the density of locations recorded to calculate probability density estimates (Worton 1989, Calenge 2007). Whilst commonly used, these approaches have associated weaknesses, for example first passage time analysis is timeconsuming, highly technical, and relies on the subjective assessment of plotted data rather than objective statistical inference (Barraquand and Benhamou 2008); it also makes untested assumptions about the link between animal movement and foraging behaviour (Fauchald and Tveraa 2003). In contrast, kernel density estimation relies on a user-defined smoothing parameter which can lead to over- or under- estimation of the extent of at-sea distributions (Row et al. 2006, Blundell et al. 2001). An alternative to these is the 'time-in-area' approach, described by Tancell et al. (2013) as "a convenient and pragmatic approach which could be applied to large data sets and across species for the identification of a network of candidate marine protected areas in coastal and pelagic waters". This involves drawing a grid of pre-defined sized cells around the colony and determining the proportion of the total time that tracked individuals spent in each pre-defined cell, which allows important at-sea distributions of the sample of birds to be identified (Le Corre et al. 2012, Page et al. 2006, Soanes et al. 2013).

This time-in area approach provides an objective representation of actual areas of use. Grid cell size can also be set to reflect the aim of the study. For example, small grid cells (e.g. I x I km) may be most appropriate for relating bird movements to environmental characteristics, to match the scale of most bathymetric and satellite-derived environmental data (e.g. SST and chlorophyll a abundance), whilst a larger scale may be preferable for marine spatial planning relating to activities such as fisheries, renewable energy developments and mineral extraction (Kidd et al. 2011).

We have previously used the time-in-area approach to assess if the at-sea distribution identified from given samples of tracked birds was representative of the area used by the whole colony (Soanes et al. 2013). However, we did not consider the effect of grid size on our predictions. Here, we develop this approach using data from one of the first tracking studies conducted on breeding seabirds in the Caribbean, specifically the UKOT of Anguilla, where we used GPS data loggers to track individuals from the globally important Brown Booby Sula leucogaster colony breeding on the Dog Island terrestrial IBA (Birdlife International 2012; Figure 1).

The data collected provide important preliminary seabird spatial distribution information for the Dog Island IBA which will be used to inform future tracking studies in the region. As such, we assess how representative the results from our sample are likely to be of the at-sea distribution of the whole colony and compare these with at-sea distributions predicted from the BirdLife International seaward extensions approach, using data from previous tracking studies. We also highlight the need to consider how increasing grid cell size can decrease the number of birds that need to be tracked from the colony in order to identify important at-sea distributions of the colony as a whole. 


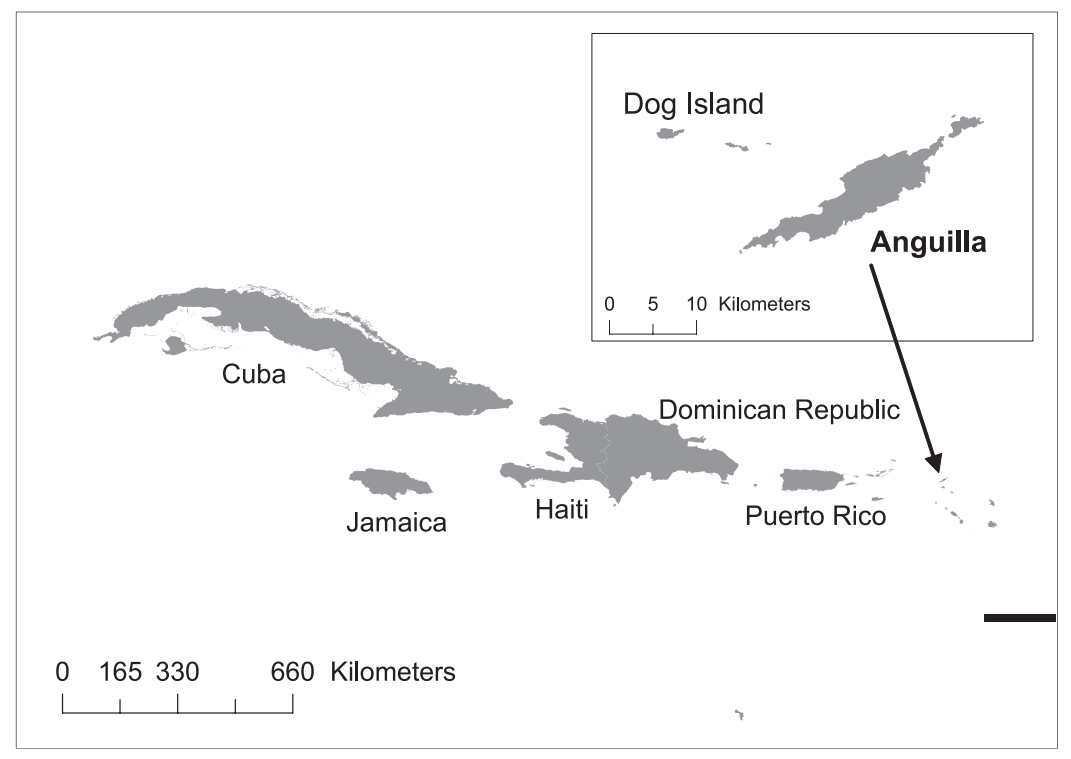

Figure 1. Location of Anguilla, Lesser Antilles in relation to other Caribbean islands (Source: ArcGIS Desktop: Release 1o. Redlands, CA: Environmental Systems Research Institute).

\section{Methods}

Fieldwork was conducted on Dog Island, Anguilla (18016'N, 63015'W) between 27 March and 4 April 2012. Twenty Brown Boobies with chicks aged 4-5 weeks were captured at their nests using a crooked pole. Females could be easily distinguished from males by the pink rather than blue tinge of their bills (Weimerskirch et al. 2009). GPS data loggers (IgotU G12O, Mobile Action, Taiwan) were waterproofed with heat-shrink PVC tubing and attached to the bird's central 2-3 tail feathers using Tesa ® Extra Power tape (Wilson et al. 1997). Data loggers weighed c.17g which on average constituted $1.2 \%$ of the mean body mass of female birds and $1.6 \%$ of males. Loggers were scheduled to record GPS locations every two minutes, and were retrieved 5-7 days after deployment.

Data were interpolated to Io second intervals using the R package "trip" (Sumner, 201I) and plotted in Arcmap (ArcGIS Desktop: Release 1o. Redlands, CA: Environmental Systems Research Institute). Foraging trips were identified and the total trip duration (hrs), distance (km), and maximum distance travelled from the breeding colony $(\mathrm{km})$ calculated for each one.

The trip package was used to create a grid of time spent in pre-defined cells from the interpolated data. This package allows the user to set the size of grid cells before calculating the time birds spend in each cell. At-sea distributions are commonly described in terms of "utilisation distribution" (UD) (Ford 1979, Kappes et al. 2011, Copello et al. 2013). We define the 95\% UD as the grid cells where $95 \%$ of all time was spent, when cells were ranked in order by seconds spent in them, and the $50 \%$ UD as the grid cells where $50 \%$ of all time was spent (Worton 1989, Soanes et al. 2013). A further intermediate $75 \%$ UD was also defined. We simulated BirdLife International's seaward extension approach based on maximum foraging distances using the maximum foraging range recorded from the present study and a previous study of Brown Boobies (Weimerksirch et al. 2009).

We estimated the areas of the $95 \%, 75 \%$ and $50 \%$ UDs following the procedure outlined by Soanes et al. (2013), by assuming an asymptotic relationship between the number of birds tracked and the percentage of the area of the whole colony UD. We used a bootstrapping procedure 
(BirdLife International 2010), implemented in the R package Boot (Canty and Ripley 2007), to randomly resample the UD of $1-16$ individuals and then plotted the number of individuals included in the sample against the size of the predicted sample UD. The most appropriate asymptotic model to fit our data was identified as the Michaelis-Menten model, based on AIC values and ability of the model to extrapolate the data (Equation I). Multiple trips were included from each individual as this gives more information on the size of the whole colony's UD (Soanes et al. 2013). However as not all tracked individuals made the same number of foraging trips, we restricted analysis to the first three trips per individual, and to the 16 individuals that made at least three trips, as a compromise between including the most birds and the most individual foraging trips in the sample to avoid pseudo-replication. Data were re-sampled 10,000 times and $95 \%$ confidence limits estimated as the $2.5^{\text {th }}$ and $97 \cdot 5^{\text {th }}$ percentiles. We assessed the effect of using four different grid cell sizes ( $2 \times 2 \mathrm{~km}, 5 \times 5 \mathrm{~km}$, 10 x 10 km and $20 \times 20 \mathrm{~km}$ ) on predictions of the UDs of our sample of birds by repeating this procedure for each grid cell size.

Equation 1: Michaelis-Menten model:

$$
y=\frac{a x}{b+x}
$$

Where $a=$ the asymptotic value of the $\mathrm{y}$ axis, and $b=$ the value of $\mathrm{x}$ at which half of the maximum response is attained

We then extrapolated each of the nonlinear model functions to estimate the area of the Dog Island colony's 50\%, 75\% and 95\% UDs, based on colony size. We used these nonlinear functions to calculate UD sizes, using varying numbers of birds and sizes of grid cell, and expressed this as a percentage of the predicted UDs for our sample of birds. Plotting these percentages as a three dimensional surface allowed rapid visual evaluation of the size of the at-sea areas that would be estimated using different sampling and grid cell size protocols. Finally, we used our models to calculate how many birds would need to be tracked to estimate $95 \%$ of the colony's $50 \%, 75 \%$ and $95 \%$ utilisation distributions. We selected $95 \%$ here due to the asymptotic nature of the relationships. See Soanes et al. (2013) for a more detailed description of this methodology.

\section{Results}

Data loggers were retrieved from 19 of the 20 Brown Boobies, with the remaining bird evading recapture. Individuals made between two and seven foraging trips during the $5-7$ day tracking period (individual tracks are shown in Figure 2a). Table 1 shows the mean trip length, duration and maximum distance from the colony travelled by Brown Boobies breeding on Dog Island, compared to those breeding at colonies in Mexico and the Johnston Atoll, Pacific Ocean (Lewis et al. 2005, Weimerskirch et al. 2009). However, it should be noted that these differences could also be due to the three studies being undertaken at different stages of the breeding cycle. Figure 2 shows the foraging trips made by Brown Boobies tracked on Dog Island along with two seaward extensions to the breeding colony $(I)$ the maximum distance from the colony recorded during this study and (2) the maximum distance from the colony recorded at a Mexican breeding colony (Weimerskirch et al. 2009). Based on this foraging radii approach (BirdLife International 2010), the maximum distance travelled from the Mexican colony predicts an estimated total at-sea area of $11,198 \mathrm{~km}^{2}$ whereas the maximum distance travelled in this study of $100 \mathrm{~km}$, predicts a foraging area of $34,247 \mathrm{~km}^{2}$. Despite the large differences in predicted foraging areas the seaward extension using the maximum distance recorded at the Mexican colony actually encompasses at least $99-100 \%$ of the $50 \%$ UD, $98-100 \%$ of the $75 \%$ UD and $86-94 \%$ of the $95 \%$ UD of the individual foraging trips made by birds tracked on Dog Island in 2013 depending on the grid cell size.

As might be expected, the extent of each of the whole colony's UD predicted by our sample increased with increasing grid cell size, but the number of birds required to predict $95 \%$ of the colony's UDs decreased (Table 2). Thus, whilst increasing the grid cell size decreased the precision 

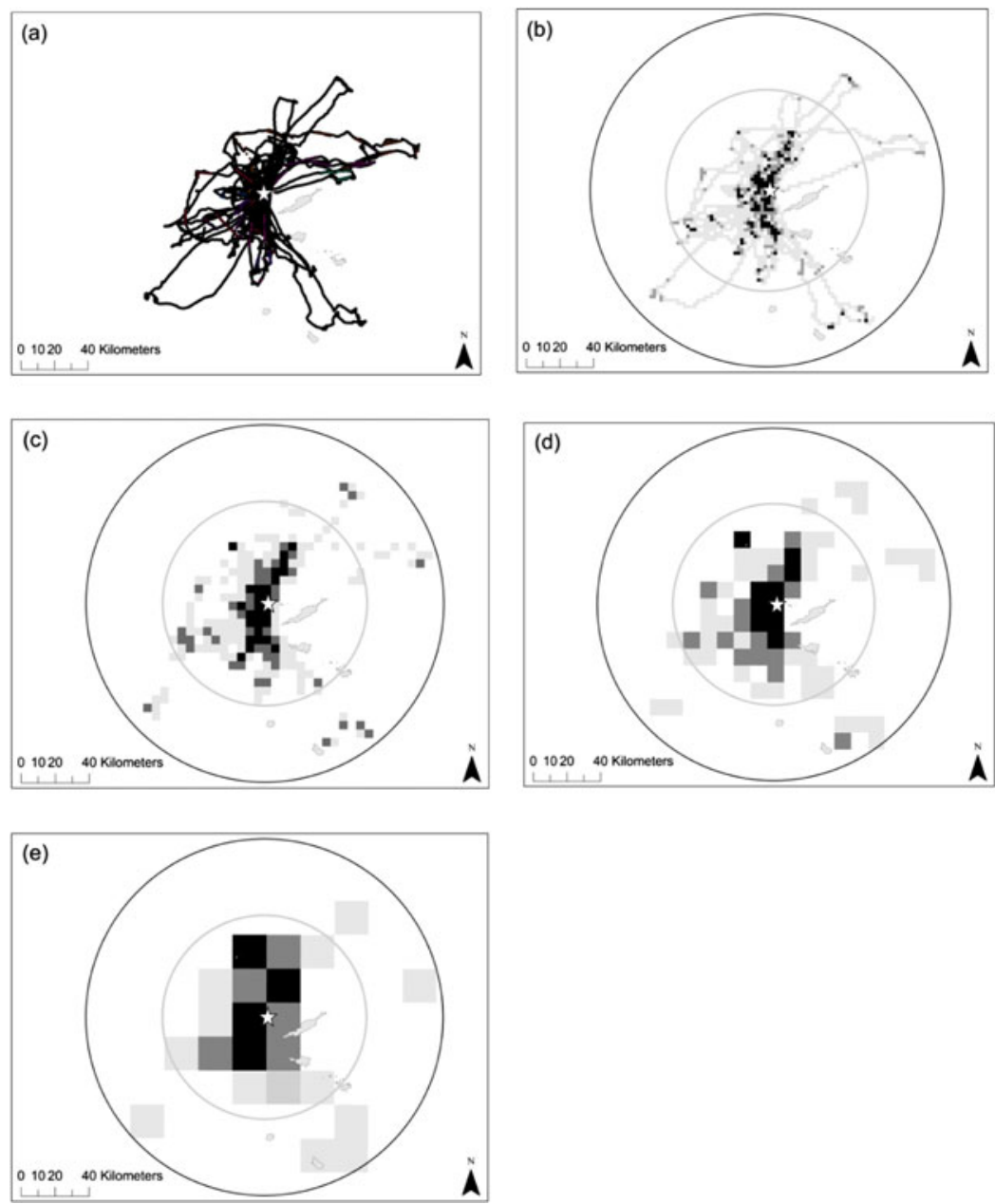

Figure 2. (a) First three foraging tracks of 16 Brown Boobies, and areas of foraging activity identified for each trip when using time spent in cells of a grid with resolution of (b) $2 \times 2 \mathrm{~km}$ (c) $5 \times 5 \mathrm{~km}$ (d) $10 \times 10 \mathrm{~km}$ and (e) $20 \times 20 \mathrm{~km}$. Light grey cells = where the sample of birds spent $95 \%$ of time, dark grey $=75 \%$ of time and black $=50 \%$ of time. All panels also show the predicted foraging radii of the colony based on the furthest point from the colony recorded from this study (black circle), and a previous tracking study of Brown Boobies (inner grey circle) (Weimerskirch et al., 2009).

of the boundary of the at-sea area used, it increased the coverage of total area used by the Dog Island colony (Figure 2). Figure 3 shows how the percentage of the area of the sample UDs predicted increases when more individuals are included in a sample, or when a larger grid cell is defined. Our sample of 16 birds would have predicted between 48 and $83 \%$ (depending on grid cell defined) of the whole colony's $50 \%$ UD, 62 and $78 \%$ of the $75 \%$ UD and between 43 and $55 \%$ of the $95 \%$ UD. The $50 \%$ UD is clearly of great importance to the birds since, irrespective of grid cell size chosen, the birds spent $50 \%$ of their time in an area less than 10\% of the size of the $95 \%$ UD (Table 2) and even our limited sample was accurate in identifying the majority of the colony's predicted at-sea distribution at the coarsest scale used. 


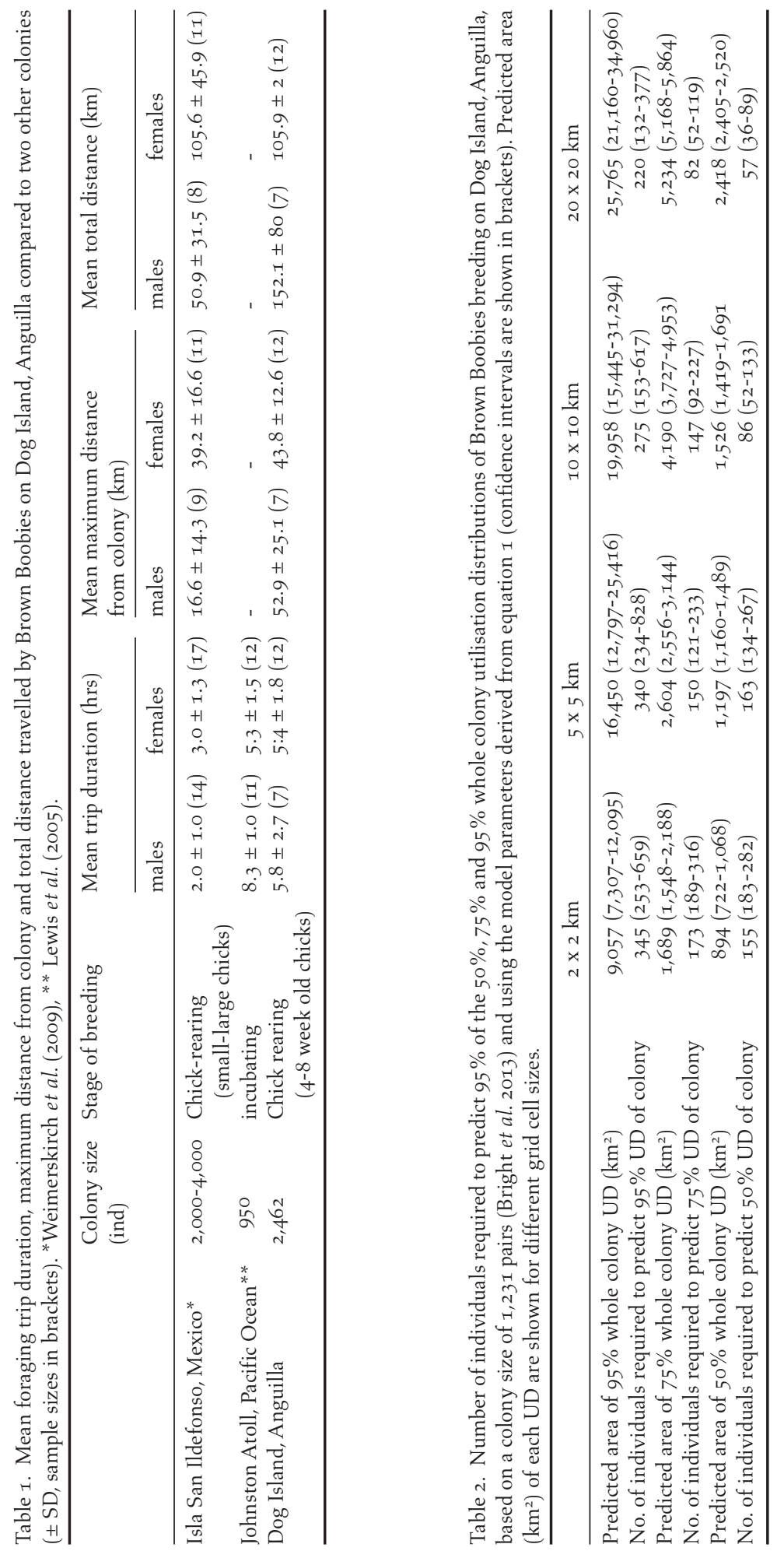



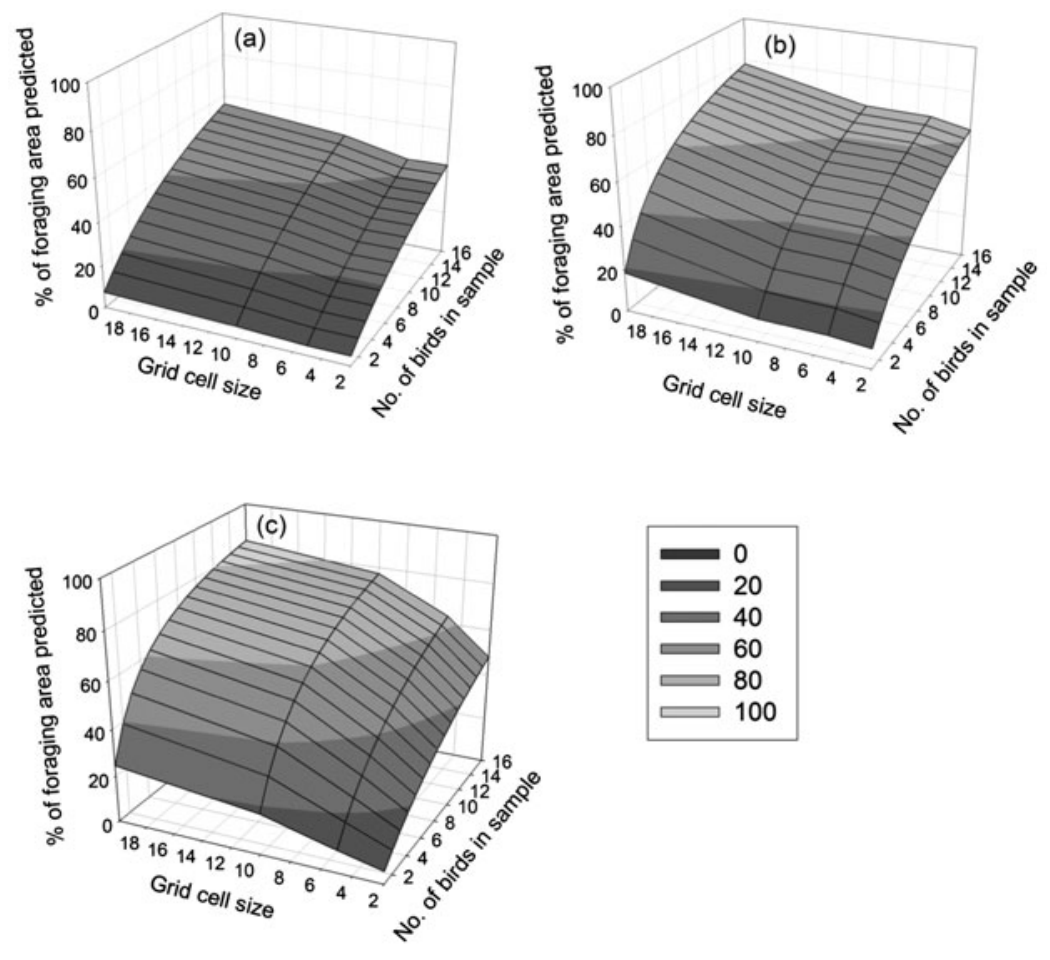

Figure 3. Percentage of the predicted utilisation distribution of the whole colony as a function of number of individuals tracked and size of grid cells used to make predictions $(2 \times 2 \mathrm{~km}, 5 \times 5 \mathrm{~km}$, 10 $\mathrm{x}$ 10 $\mathrm{km}$ and $20 \times 20 \mathrm{~km}$ ) for (a) $95 \%$ utilisation distribution (b) $75 \%$ utilisation distribution and (c) $50 \%$ utilisation distribution.

\section{Discussion}

We present results from one of the first seabird tracking studies undertaken in the Caribbean, for the globally important colony of Brown Booby breeding on Dog Island, Anguilla, one of the most important sites for seabirds in the region (Lowrie et al. 2012). The mean foraging trip length, and maximum distance travelled of the tracked birds were longer than those of Brown Boobies in Mexico (Weimerskirch et al. 2009), but mean trip duration was comparable to that of the Johnston Atoll colony in the Pacific Ocean (Lewis et al. 2005) (Table 1). Foraging trips made by Brown Boobies on Dog Island extended beyond Anguilla's Exclusive Economic Zone and into those of neighbouring Sint Eustatius and Saba (territories of the Netherlands), Saint Barthelemy (territory of France) and Saint Maarten/Sint Martin (territory of France and the Netherlands). Ensuring the multinational protection of important habitats for such wide ranging species presents a challenge to governments and environmental organisations, but is essential to achieving successful conservation. The results from this and future studies will be relevant to multinational initiatives such as the Caribbean Challenge (Nature Conservancy 2013) and in informing how seabird tracking data can be used to define Marine Protected Areas.

Identification of important foraging areas is essential in order to show the areas where protection of breeding seabird populations is most needed and can help inform the design, designation and management of protected areas. In the absence of tracking data, BirdLife International (2010) suggests using a seaward extension approach based on known foraging radii. Our study shows that this approach has potential in the identification of areas that are likely to encompass the most 
heavily used areas (50 and 75\% UDs) but still risks under-representing all key at-sea areas for the Dog Island Brown Booby colony. Ideally, several datasets from different colonies over different years should be used to inform the seaward extension approach. The size of the colony is also a key factor in the foraging behaviour of seabirds (Wakefield et al. 2013) and would be a useful refinement that should be incorporated into future predictive models in the absence of colony-specific tracking data.

The logistics of seabird tracking studies, including time and budgetary constraints, mean that sample sizes are often low. To begin to make population-level conservation decisions using tracking data it is vital to assess the representativeness of such small samples in predicting important at-sea areas for the wider population. Our analysis indicates that our sample of 16 birds only identified $43-55 \%$ of the Dog Island colony's $95 \%$ UD and $48-83 \%$ of the colony's $50 \%$ UD. Thus, many more individuals from this colony would need to be tracked to fully identify the $95 \%, 75 \%$ and $50 \%$ UDs for this colony (Table 2, Figure 2), though this number decreases with increasing grid cell size. For example, if using a 2 x $2 \mathrm{~km}$ grid cell to estimate the $50 \%$ UD then 155 (CI $183-282$ ) individuals would be required, compared to just 57 (CI 36-89) when a coarser spatial scale of $20 \mathrm{x}$ $20 \mathrm{~km}$ is defined. Increasing grid cell size should therefore increase the coverage of the whole colony's at-sea distribution, since there is a greater chance of including key areas for a given sample size. However precision will be decreased as the coarse scale is likely to include areas not actually used by birds. The exact grid cell size to be selected will be a question for marine planners and policy makers and depend on the scale at which other marine spatial planning decisions are made (Kidd et al. 2011). An additional way of increasing the representativeness of the sample would be to include a greater number of foraging trips for each individual (see Soanes et al. 2013), but this is made difficult by the limited battery life of commonly used low-cost GPS data loggers.

Understanding seabird foraging behaviour and identifying important at-sea areas are key to minimising the impact of the increasing global pressures on our marine ecosystems, through activities such as fisheries and marine renewable energy development. Accurate and representative species distribution information is essential to assessing how area use varies over time and to aid species protection via the designation of Marine Protected Areas. Seabird populations in the UKOTs are currently understudied, despite their global importance, and studies such as this investigating seabird foraging behaviour and identifying important at-sea areas for seabirds are crucial to redress this.

\section{Acknowledgements}

Thanks to Mr Karim Hodge of the Department of Environment and to the Government of Anguilla for granting research permissions for this work. Thanks to the Anguilla National Trust staff and volunteers for logistical support and the Dog Island rat eradication team for making us welcome and supporting our research, in particular Elizabeth 'Biz' Bell (Wildlife Management International Ltd.). Thanks also to Steve Holliday, Colin Wilkinson and Steffen Oppel for advice on planning the fieldwork. We are also grateful to the anonymous reviewers who provided constructive comments on previous drafts of this work.

\section{References}

Arcos, J. M., Becares, J., Villero, D., Brotons, L., Rodriguez, B. and Ruiz, A. (2012) Assessing the location and stability of foraging hotspots for pelagic seabirds: An approach to identify marine Important Bird Areas (IBA's) in Spain. Biol. Conserv. 156: 30-52.

Barraquand, F. and Benhamou, S. (2008) Animal movements in heterogeneous landscapes:identifing profitable places and homogenus movement bouts. Ecology 89: 3336-3348.

Bertrand, S., Rocio, J., Arbulu Smet, C., Tremblay, Y., Barbraud, C. and Weimerskirch, H. (2012) Local depletion by a fishery can affect seabird foraging. J. Appl. Ecol. 49: 1365-2664.

BirdLife International (2010) Marine Important Bird Areas toolkit: standardised techniques 
for identifiing priority sites for the conservation of seabirds at sea. Cambridge, UK: Birdlife International.

BirdLife International (2012) Important Bird Areas in the Caribbean: key sites for conservation. Cambridge, UK: Birdlife International.

Bright, J., Soanes, L., Mukhida, F., Brown, R., and Millett, J. (In press) Baseline seabird surveys on Dog Island following rat eradication - reveal globally important red-billed tropicbird population. J. Caribbean Ornithol.

Blundell, G. M., Maier, J. A. K. and Debevec, E. M. (2001) Linear home ranges: Effects of smoothing, sample size, and autocorrelation on kernel estimates. Ecol. Monogr. 71: 469-489.

Burger, A. E. and Shaffer, S. A. (2008) Application of tracking and data-logging technology in research and conservation of seabirds. Auk 125: 253-264.

Canty, A. and Ripley, B. (2011) boot: Bootstrap R (S-Plus) Functions. R package version 1.3-2.

Calenge, C. (2007) Exploring habitat selection by wildlife with adehabitat. J. Statistical Softw. 22: 1-19.

Copello, S., Pon, J. P. S. and Favero, M. (2013) Use of marine space by Black-browed albatrosses during the non-breeding season in the Southwest Atlantic Ocean. Estuar. Coast. Shelf Sci. 123: 34-38.

Croxall, J. P., Butchart, S. H. M., Lascelles, B., Stattersfield, A. J., Sullivan, B., Symes, A. and Taylor, P. (2012) Seabird conservation status, threats and priority actions: a global assessment. Bird Conserv. Internatn. 22: 1-34.

Fauchald, P. and Tveraa, T. (2003) Using firstpassage time in the analysis of area-restricted search and habitat selection. Ecology 84: 282-288.

Ford, R. G. (1979) The analysis of space use patterns. J. Theor. Biol. 76: 125-155.

Gremillet, D. and Boulinier, T. (2009) Spatial ecology and conservation of seabirds facing global climate change: a review. Mar. Ecol.Progr. Ser. 391: 121-137.

Hilton, G. M. and Cuthbert, R. J. (2010) The catastrophic impact of invasive mammalian predators on birds of the UK Overseas Territories: a review and synthesis. Ibis 152 : 443-458.
Kappes, M. A., Weimerskirch, H., Pinaud, D. and Le Corre, M. (2011) Variability of resource partitioning in sympatric tropical boobies. Mar. Ecol.-Progr. Ser. 441: 281-294.

Kidd, S., Plater, A. and Frid, C. (2011) The ecosystem approach to marine planning and management. New York, USA: Earthscan.

Le Corre, M., Jaeger, A., Pinet, P., Kappes, M. A., Weimerskirch, H., Catry, T., Ramos, J. A., Russell, J. C., Shah, N. and Jaquemet, S. (2012) Tracking seabirds to indentify potential Marine Protected Areas in the tropical western Indian Ocean. Biol. Conserv. 156: 83-93. Lewis, S., Schreiber, E. A., Daunt, F., Schenk, G. A., Orr, K., Adams, A., Wanless, S. and Hamer, K. C. (2005) Sex-specific foraging behaviour in tropical boobies: does size matter? Ibis 147: 408-414.

Lewison, R., Oro, D., Godley, B. J., Underhill, L., Bearhop, S., Wilson, R. P., Ainley, D., Arcos, J. M., Boersma, P. D., Borboroglu, P. G., Boulinier, T., Frederiksen, M., Genovart, M., Gonzalez-Solis, J., Green, J. A., Gremillet, D., Hamer, K. C., Hilton, G. M., Hyrenbach, K. D., Martinez-Abrain, A., Montevecchi, W. A., Phillips, R. A., Ryan, P. G., Sagar, P., Sydeman, W. J., Wanless, S., Watanuki, Y., Weimerskirch, H. and Yorio, P. (2012) Research priorities for seabirds: improving conservation and management in the 21st century. Endangered Species Res. 17: 93.

Lowrie, K., Lowrie, D. and Collier, N. (2012) Seabird breeding atlas of the Lesser Antilles. Saint Maartin: Environmental Protection in the Caribbean (EPIC).

Nature Conservancy (2013) Caribbean Challenge. http://www.nature.org/ourinitiatives/ regions/caribbean/caribbean-challenge. $\mathrm{xml}$

O'Brien, S. H., Webb, A., Brewer, M. J. and Reid, J. B. (2012) Use of kernel density estimation and maximum curvature to set Marine Protected Area boundaries: Identifying a Special Protection Area for wintering redthroated divers in the UK. Biol. Conserv. 156: 15-21.

Oppel, S., Meirinho, A., Ramirez, I., Gardner, B., O'Connell, A. F., Miller, P. I. and Louzao, M. (2012) Comparison of five modelling techniques to predict the spatial distribution and abundance of seabirds. Biol. Conserv. 156: 94-104. 
Page, B., McKenzie, J., Sumner, M. D., Coyne, M. and Goldsworthy, S. D. (2006) Spatial separation of foraging habitats among New Zealand fur seals. Mar. Ecol-Progr. Ser. 323: 263-279.

Pinaud, D. (2008) Quantifying search effort of moving animals at several spatial scales using first-passage time analysis: effect of the structure of environment and tracking systems. J. Appl. Ecol. 45: 91-99.

Row, J. R. and Blouin-Demers, G. (2006) Kernels are not accurate estimators of home-range size for herpetofauna. Copeia 4: 797-802.

RSPB/FIELD (2013) An assessment of environmental protection frameworks in the UK Overseas Territories. Report by the Foundation for International Environmental Law and Development (FIELD) and The Royal Society for the Protection of Birds (RSPB). Sandy, UK: RSPB. (www.rspb.org. uk/overseasterritories)

Sanders, S. (2006) Important Bird Areas in the United Kingdom Overseas Territories: Priority sites for conservation. Sandy, UK: Royal Society for the Protection of Birds.

Soanes, L., Arnould, J., Dodd, S., Sumner, M. and Green, J. (2013) How many seabirds do we need to define home-range area. J. Appl. Ecol. 50: 671-679.

Sumner, M. D. (2011) trip: Spatial analysis of animal track data. $R$ package version I.I-IO.

Suryan, R. M., Sato, F., Balogh, G. R., Hyrenbach, K. D., Sievert, P. R. and Ozaki, K. (2004) Foraging destinations and marine habitat use of short-tailed albatrosses:
A multi-scale approach using first-passage time analysis. Pp. 370-386 in 13th Annual Meeting of the North-Pacific-MarineScience-Organization (PICES) Honolulu, HI. Tancell, C., Phillips, R. A., Xavier, J. C., Tarling, G.A. and Sutherland, W. J. (2013) Comparison of methods for determining key marine areas from tracking data. Mar. Biol. 160: 15-26.

Wakefield, E. D., Bodey, T. W., Bearhop, S., Blackburn, J., Colhoun, K., Davies, R., Dwyer, R. G., Green, J. A., Gremillet, D., Jackson, A. L., Jessopp, M. J., Kane, A., Langston, R. H. W., Lescroel, A., Murray, S., Le Nuz, M., Patrick, S. C., Peron, C., Soanes, L. M., Wanless, S., Votier, S. C. and Hamer, K. C. 2013 Space partitioning without territoriality in Gannets. Science 341: 68-70.

Weimerskirch, H., Shaffer, S. A., Tremblay, Y., Costa, D. P., Gadenne, H., Kato, A., RopertCoudert, Y., Sato, K. and Aurioles, D. (2009) Species- and sex-specific differences in foraging behaviour and foraging zones in blue-footed and brown boobies in the Gulf of California. Mar. Ecol-Progr. Ser. 391: $267-278$.

Wilson, R. P., Pütz, K., Peters, G., Culik, B., Scolaro, J. A., Charrassin, J.-B. and RopertCoudert, Y. (1997) Long-term attachment of transmitting and recording devices to penguins and other seabirds. Wildl. Soc. Bull. 25: 101-106.

Worton, B. J. (1989) Kernel methods for estimating for utilization distribution in homerange studies. Ecology 70: 164-168.

LOUISE M. SOANES*, JONATHAN A. GREEN

School of Environmental Sciences, University of Liverpool, L69 3 GP, UK.

JENNIFER A. BRIGHT, MARK BOLTON, JAMES MILLETT

RSPB Centre for Conservation Science, RSPB, The Lodge, Sandy, Bedfordshire, SG19 2DL, UK.

FARAH MUKHIDA

Anguilla National Trust, P.O. Box 1234, The Valley, AI-2640 Anguilla, British West Indies.

*Author for correspondence; email: louise.soanes@liv.ac.uk

Received 15 May 2013; revision accepted 5 February 2014; Published online 1o April 2014 